\title{
Update on major clones of methicillin-resistant Staphylococcus aureus colonizing and/or infecting humans and its distribution in Brazil
}

\section{Atualização sobre clones principais de staphylococcus aureus resistente à meticilina colonizando elou infectando humanos e sua distribuição no Brasil}

\author{
Thaina Miranda da Costa $^{1}$ \\ Valéria Vieira ${ }^{3}$ \\ Fábio Aguiar Alves ${ }^{1,2}$
}

Artigo

Original

Original

Paper

\section{Key words \\ Methicillin-resistant \\ Staphylococcus \\ aureus}

Nasal colonization

Infection

Genotypes

\begin{abstract}
Staphylococcus aureus is a bacterium well known for its ability to acquire genes for resistance to antimicrobial drugs. A few years after the discovery of penicillin, which initiated the era of antibiotics, resistance to this drug had already been reported in hospitals and in a few decades also became a problem within the communities. Likewise, shortly after the introduction of methicillin as a therapeutic option, the resistance was observed. The indiscriminate use of antibiotics is an important factor contributing to the emergence of new resistant strains. This pathogen has the ability to spread rapidly and asymptomatically among healthy individuals. Infections caused by Methicillin-Resistant Staphylococcus aureus (MRSA) have reached a global share and are increasing in hospitals and community, including countries that previously had a low prevalence of MRSA history, exposing a significant diversity of clones identified. Outbreaks of infections caused by strains of Community-Associated Methicillin-Resistant Staphylococcus aureus (CA-MRSA) have been reported worldwide, including Brazil, where there is currently an epidemic of CA-MRSA. The present article intends to review the molecular epidemiology of methicillin-resistant Staphylococcus aureus and its evolution, with a focus on the clones distributed in Brazil.
\end{abstract}

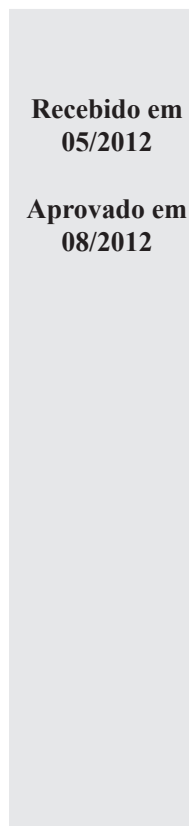

\section{Resumo}

Staphylococcus aureus é um bactéria muito conhecida por sua capacidade de aquisição de genes de resistência à drogas antimicrobianas. Alguns anos após a descoberta da penicilina, que iniciava a era dos antibióticos, a resistência a esta droga já foi relatada em hospitais e em poucas décadas também tornou-se um problema dentro das comunidades. Do mesmo modo, logo após a introdução de meticilina como uma opção terapêutica, a resistência foi observada. O uso indiscriminado de antibióticos é um importante fator contribuindo para o surgimento de novas cepas. Este patógeno tem a capacidade de espalharse rapidamente e assintomaticamente entre indivíduos saudáveis. Infecções causadas por Staphylococcus aureus resistente à meticilina (SARM) atingiu uma cota global e está aumentando em hospitais e comunidades, incluindo países que previamente tinham um baixa prevalência de história de SARM, expondo uma diversidade significante de clones identificados. Surtos de infecções causadas por cepas de Staphylococcus aureus resistente à meticilina de Comunidades Associadas (SARM-CA) foram relatados no mundo, incluindo Brasil, onde há atualmente uma epidemia de SARM-CA. O presente artigo pretende revisar a epidemiologia molecular de Staphylococcus aureus resistente à meticilina e sua evolução, com o foco em clones distribuídos no Brasil.

\section{Palavras-chave}

Staphylococcus aureus resistente à meticilina

Colonização nasal

Infecção

Genótipos

1 Programa de Pós-Graduação em Patologia - Faculdade de Medicina - Universidade Federal Fluminense - Niterói - Brasil. 2 Polo Universitário de Nova Friburgo - Universidade Federal Fluminense - Nova Friburgo - Brasil. 


\section{Introduction}

A wide variety of infections, both superficial and deep, may be caused by Staphylococcus aureus (DEURENBERG \& STOBBERINGH, 2008; COREY, 2009; CECCARELLI, 2011).

$S$. aureus can be permanent or intermittently present in the microbiota of nares, skin, throat and intestinal tract of some individuals. This colonization allows those subjects to act as disseminators of this microorganism. Also, these individuals are at higher risk for infection (RAMOS, 1999; CONLY \& JOHNSTON, 2003). Nowadays it is believed that $30 \%$ of humans have asymptomatic nasal colonization by S. aureus (CHAMBERS \& DELEO, 2009; RODRIGUEZ-NORIEGA, 2010).

Transmission occurs by direct contact, usually through skin from a person colonized or infected having open lesions. Other routes such as fomites and hands of health professionals are also important means of transmission. More recently, several outbreaks of methicillinresistant Staphylococcus aureus (MRSA) have been associated with the presence of samples in food of animal origin (RIZEK, 2011).

The spread is facilitated by several reasons including the migration of population, including health professionals, combined with ineffective methods to control transmission of MRSA from colonized and infected patients, along with inappropriate use of antimicrobials (DEURENBERG \& STOBBERINGH, 2008; RODRIGUEZ-NORIEGA \& SEAS, 2010).

The mechanism of resistance is also an important factor to be observed among these microorganisms. S. aureus is naturally susceptible to all antimicrobials that were developed (DANCER, 2008). The resistance to these drugs is generally acquired by horizontal gene transfer but chromosome mutation and selective pressure imposed by antibiotics are also important (DEURENBERG \& STOBBERINGH, 2009). Thus, the diversity of $\mathrm{S}$. aureus clones that exists nowadays is genetically descendant from a single common ancestor (KLEVENS, 2007; RODRIGUEZNORIEGA, 2010).

Currently, there is an increase of Community-Associated Methicillin-Resistant
Staphylococcus aureus (CA-MRSA) infections worldwide, mostly characterized by cutaneous and soft tissue lesions among healthy individuals without predisposing risk factors. Nevertheless, after the emergence of CA-MRSA, symptoms of necrotizing pneumonia and fulminating necrotizing fasciitis became more common in infections, showing a particularly virulent characteristic of these strains (VANDENESCH, 2003; LO \& WANG, 2011).

The present article proposes to make a brief review about main MRSA clones causing infection and colonization in Brazil.

\section{Methods}

Thereview was made using reports published from 1993 to nowadays, also including the first articles related to $\mathrm{S}$. aureus resistance (dated from 1949). Data collection included a literature held in scientific search sites like PubMed, LILACS, Scielo, BIREME and Scholar google. Keywords used were: methicillin-resistant Staphylococcus aureus, nasal colonization, infection, genotypes, hospital, community and Brazil.

\section{Results}

A total of 63 articles, one homepage (International Working Group on the Staphylococcal Cassette Chromosome elements homepage) and one Brazilian Law (Law no. 9431/1997) were selected in order to characterize a review of the molecular epidemiology of major clones of MRSA pathogen to human, its evolution and distribution in Brazil.

\subsection{Staphylococcus aureus history and evolution}

The beginning of clinical use of penicillin occurred in 1940 and the first reports of resistant strains date from few years later when there was an epidemic of nosocomial infections caused by strains of $S$. aureus resistant to this drug in several countries, including Australia and the United States (RAMMELKAMP \& MAXON, 1942). In the early 50 s occurred the first cases of communityassociated infections and the establishment of a pandemic (CHAMBERS \& DELEO, 2009). 
These strains produce a penicinilase, encoded by a plasmid, which hydrolyzes the beta-lactam ring of penicillin, essential for antimicrobial activity.

At this time, the hospital and community infections were often caused by a strain known as phage type $80 / 81$ (KENNEDY, 2008) and such infections became rare after the first use of methicillin in 1960.

In the year following the beginning of methicillin therapeutic aplication, the first cases of resistance to this antibiotic were published in England and at the end of the same decade methicillin-resistant strains were already endemic in hospitals (ERIKSEN, 1961; JEVONS, 1963; DEURENBERG \& STOBBERINGH, 2009).

Methicillin resistance is conferred by the mecA gene, which is carried by a mobile genetic element known as Staphylococcal Cassette Chromosome mec (SCCmec) which encodes a penicillin-binding protein modified, called PBP2a or PBP2', which has a low affinity to betalactams, including penicillins, cephalosporins and carbapenems (KATAYAMA, 2000; KONDO, 2007; DEURENBERG \& STOBBERINGH, 2008; ZHANG, 2009; SHORE, 2011).

According to publications, so far, there are eleven different allotypes of SCCmec, types I to XI, that have been revealed among MRSA strains (CHAMBERS \& DELEO, 2009; IWG-SCC, 2011).

SCCmec presents the genetic components named mec gene complex and cassette chromosome recombinases (ccr) gene complex (ITO, 2004; KONDO, 2007; DEURENBERG \& STOBBERINGH, 2008; 2009; ZHANG, 2009; SHORE, 2011). Variations within these gene complexes serve as the primary basis for classifying the various types of SCCmec (KONDO, 2007; CHAMBERS \& DELEO, 2009).

The mec gene complex is composed of the mecA gene and its regulators, mecI and $m e c R I$. This complex also may contain genetic components such as transposons, plasmids and insertion sequences, such as the IS431 (HANSSEN \& ERICSON SOLLID, 2006; ZHANG, 2009). Five different classes of mec gene complexes, called class A, B, C1, C2 and $\mathrm{D}$ were described in the literature (KONDO, 2007; SHORE, 2011).
The $c c r$ gene complex contains the ccrA, $c c r B$ or $\operatorname{ccr} C$ genes. These encode two recombinases, which are required for integration and excision of SCCmec from the orf $\mathrm{X}$ region in the genome of $S$. aureus, thus allowing the horizontal transmission of the SCCmec (BERGLUND, 2005; HANSSEN \& ERICSON SOLLID, 2006; ZHANG, 2009). Up to date, five allotypes of $c c r$ have been described (ccrA1B1, ccrA2B2, ccrA3B3, ccrA4B4 e ccrC5) (KONDO, 2007; SHORE, 2011).

SCCmec III and IV, which are the most commonly found types in Brazil, have different characteristics according to the presentation of these mobile elements, as shown in Table 1.

First cases of CA-MRSA occurred in Australia in the early 90's in an indigenous population, by a clone known as Western Australia 1 (WA-1) (UDO, 1993). Such isolates were not related to the hospital and was susceptible to most antimicrobials that were not beta-lactams, unlike the hospital strains (LO \& WANG, 2011).

Since then, CA-MRSA is now reported worldwide in numerous populations including athletes, children attending day care centers, prisoners, men who have sex with men, military, drug users and other individuals in healthy communities that do not present any risk of infection (KLEVENS, 2007; GORWITZ, 2008; KENNEDY, 2008; STEVENS, 2008). An increase of CA-MRSA infections also happened to be found in hospitals (SCHUENCK, 2009). Thus, there is not an individual or group that is not at risk for infection by CA-MRSA.

CA-MRSA strains usually carry SCCmec type IV and, less frequently, the type V and VII (DEURENBERG \& STOBBERINGH, 2008; LO \& WANG, 2011), and generally produce the toxin Panton-Valentine Leukocidin (PVL) (KLEVENS, 2007; CHAMBERS \& DELEO, 2009).

Several important studies suggest that PVL is associated with skin infections and severe necrotizing hemorrhagic pneumonia in previously healthy patients without any risk factors for infection. These clinical features were rarely seen before the emergence of CAMRSA strains (GENESTIER, 2005; LO \& WANG, 2011). 
Hospital-Acquired Methicillin-Resistant Staphylococcus aureus (HA-MRSA) differ from CA-MRSA in terms of genetic and phenotypic characterization, as showed in table 2, being the former more susceptible to tetracycline, clindamycin and trimethoprimsulfzametoxazol (WALRAVEN, 2011).

Molecular techniques for genotyping isolates of $S$. aureus allow further study of this pathogen, allowing a more accurate understanding of the spread and evolution (ROBINSON \& ENRIGHT, 2004; CHAMBERS \& DELEO, 2009). The technique of Multilocus Sequence Typing (MLST), for example, allows clones to be classified and distinguished in Sequence Types (ST). In turn, the STs are grouped into Clonal Complexes (CC).

The clone multiresistant New York/ Japan (NYJ) is related to the clone USA100 and is ST5-SCCmecII. It can be found in some Latin American countries such as Mexico and elsewhere in the world including Australia, Belgium, Canada, China, Denmark, France and Germany and also is widely distributed in the U.S. and Japan (AIRES DE SOUSA, 2000; DEURENBERG \& STOBBERINGH, 2008).

In Australia, the WA-1 clone, related to the USA400 clone, was one of the first CAMRSA described in the world. This clone is ST1-SCCmecIV and usually does not produce PVL (DAILEY, 2005; SCHUENCK, 2009).

It is known that in most regions of the United States and Canada the main cause of severe infections, especially in skin, is the CAMRSA clone known as USA300 which is ST8SCCmecIV and PVL producer (KLEVENS, 2007; KENNEDY, 2008; CHAMBERS \& DELEO, 2009).

Other CA-MRSA clone highly distributed worldwide is the Pediatric clone, which is ST5-SCCmecIV or SCCmecV and also related to the USA800 clone (SA-LEAO, 1999; DEURENBERG \& STOBBERINGH, 2008).

\subsection{MRSA in Brazil}

In Brazil, MRSA is a major cause of nosocomial infections. The epidemic clone of MRSA in most hospitals from north to south, reported since 1994, is characterized by being multiresistant, able to produce biofilms and, in most cases, doesn't produce PVL toxin (DOS
SANTOS SOARES, 2000; RODRIGUEZNORIEGA \& SEAS, 2010). This Brazilian Epidemic Clone (BEC) is classified as SCCmecIIIA-ST239 (CC8) and belong to the same clonal complex of the first MRSA identified in the world (Figure 1) (SADER, 1994; OLIVEIRA, 2001; ROZENBAUM, 2006; ROZENBAUM, 2009).

The prevalence of nosocomial infections by $S$. aureus ranges from $40 \%$ to $80 \%$ in most Brazilian hospitals with more than $37 \%$ of these corresponding to multiresistant MRSA (VIVONI, 2006; SCHUENCK, 2009; RODRIGUEZ-NORIEGA, 2010). In recent study with MRSA samples of a university hospital in Recife, northeast of Brazil, BEC accounted for $70 \%$ of the total of samples (DE MIRANDA, 2007).

Samples of BEC are resistant to betalactams, chloramphenicol, ciprofloxacin, clindamycin, gentamicin, tetracycline, erythromycin, lincomycin, and trimethoprim-sulfamethoxazole. These clone is widespread among various hospitals in Latin America such as Argentina, Chile, Colombia, Ecuador, Paraguay, Peru and Uruguay, Europe such as Portugal, Russia and the Czech Republic and Asia such as Vietnam, Thailand and Taiwan (TEIXEIRA, 1995; MELTER, 1999; AIRES DE SOUSA, 2001; OLIVEIRA, 2001; AIRES DE SOUSA, 2003; PEREZ \& D'AZEVEDO, 2008; RODRIGUEZ-NORIEGA \& SEAS, 2010; RODRIGUEZ-NORIEGA, 2010).

In 1999 there were reports of BEC with resistance to mupirocin, a topical antibiotic used to eradicate colonization of patients and health professionals (RAMOS, 1999).

In Brazil, factors as hospitals overcrowding, transference of patients between hospitals and the lack of an effective control of infection and antibiotics use, facilitated the spread of BEC between the cities (OLIVEIRA, 2001).

Despite this, studies have reported an increase presence of non-multiresistant MRSA SCCmec type IV, characteristic of samples associated with communities, in individuals admitted to hospitals, showing a change in the molecular profile of samples in Brazilian hospitals (Figure 2) (RIBEIRO, 2005; SAID-SALIM, 2005; DE MIRANDA, 2007; REINERT, 2008; SCHUENCK, 2009; SCRIBEL, 2009; SILVA-CARVALHO, 2009; 
SOUSA-JUNIOR， 2009; RODRIGUEZNORIEGA \& SEAS, 2010; RODRIGUEZNORIEGA, 2010; ROSSI, 2011).

The NYJ clone has been identified in national studies since 2004, being found in hospital samples in Rio de Janeiro and Recife (MELO, 2004; DE MIRANDA, 2007).

The clone Oceania Southwest Pacific clone is SCCmecIV-ST30 and was the first of this type of SCCmec to be reported in the country and throughout Latin America in 2005 (RIBEIRO, 2005; RODRIGUEZNORIEGA \& SEAS, 2010). This clone is PVL producer and causes primarily skin infections, septic arthritis and soft tissue infections in immunocompetent individuals in communities (SILVA-CARVALHO, 2009).

In 2009 , a study conducted with samples of non-multiresistant MRSA, from a hospital in Rio de Janeiro, showed a presence of polyclonal SCCmec type IV (SCHUENCK, 2009).

As described in the literature, CAMRSA infections are caused by different genotypes belonging to different sequence types (CHAMBERS \& DELEO, 2009). In Brazil, SCCmec type IV samples belonging to sequence types ST1, ST3, ST5, ST8, ST30, ST72, ST88 and ST97 have already been found (REINERT, 2008; SCHUENCK, 2009; SILVA-CARVALHO, 2009).

Variants of the Pediatric clone which is SCCmec type IV have been reported causing infections in hospitals in Rio de Janeiro, Recife and Porto Alegre (ROZENBAUM, 2006; DE MIRANDA, 2007; SCRIBEL, 2009).

In 2007 the first report of USA300 in the country was published. It was collected in the end of 2003 in Porto Alegre (RIBEIRO, 2007). At the same scientific publication there was the report of WA-1 clone in Porto Alegre and Rio de Janeiro in samples collected in 2004.

One of the main pathogens of infective endocarditis, MRSA is the etiologic agent of $37.5 \%$ of these infections in Brazil (FOWLER, 2005). The first report of this disease caused by CA-MRSA in the country occurred in 2008 , by a sample of SCCmec type IV and PVL positive (FORTES, 2008). Although BEC samples with intermediate resistance to vancomycin and teicoplanin have already been reported in northeastern Brazil in 2000 (DOS SANTOS SOARES, 2000), these isolates remain rare in this country.

\section{Discussion}

Despite the association of $S$. aureus with abscess formation and sepsis have been reported in the late seventeenth century, this bacterium remains an important cause of infections acquired in both hospital and community environments.

Staphylococcal infections vary from located, usually superficial, to deep, with high gravity (COREY, 2009).

Studies that characterize the circulating strains in specific environments help to control this pathogen, which is the major cause of infections in surgical wounds and sepsis in hospitalized patients (LINDSAY \& HOLDEN, 2004; CHAMBERS \& DELEO, 2009).

Currently, this bacterium has increasing clinical importance due to increased rates of infections related to health care and community infections caused by multiresistant strains (ALLEGRANZI, 2011).

Outbreaks occur throughout the world with a similar epidemiology and MRSA clones are rarely confined to a single hospital, affecting, generally, all the hospitals in a region (LEE, 2011). Despite this, the occurrence of specific clones, with specific standards of resistance, may vary according to the geographic region (SCHUENCK, 2009; RODRIGUEZ-NORIEGA \& SEAS, 2010).

In Brazil, factors such as overcrowding hospitals, transfer of patients between hospitals and the lack of effective control of infection and antibiotic use has facilitated the spread of MRSA by cities (OLIVEIRA, 2001). In addition, studies have reported an increased presence of SCCmec type IV MRSA, characteristic of samples associated with communities, in individuals admitted to hospital with infections diagnosed after 48 hours of admission, indicating a change in the molecular profile of the Brazilian hospital samples (DE MIRANDA, 2007; SCRIBEL, 2009; SILVA-CARVALHO，2009; SOUSAJUNIOR, 2009; RODRIGUEZ-NORIEGA \& SEAS, 2010).

In order to monitor infections related to healthcare in Brazil the Law no. 9431 of January 6, 1997 provides for the obligation of hospitals to maintain a Program of Control of Hospital Infections and create a Committee of Nosocomial Infection Control (BRASIL, 1997). 
Factors such as the immediate increase in the treatment cost due to the use of more expensive alternative antibiotics and their impact on other micro-organisms demonstrate the importance of these infections in terms of public health.

Moreover, increased hospitalization, the potential loss of productivity of infected patients, the possibility of intractable infection and increased mortality indicate the urgency to the study and prevention of infections caused by MRSA.

\section{Final considerations}

The indiscriminate use of antibiotics is an important factor contributing to the emergence of new resistant strains. The correct identification of MRSA is essential to ensure proper treatment of patients. More studies are necessary to maintain the surveillance and to allow the identification of changes in the resistance profile of clones circulating in Brazil, allowing the updated of knowledge of epidemiology of MRSA and more targeted measures to appropriately control the dissemination of this organism.

\section{Acknowledgment}

We thank the collaboration of the Postgraduate Program of Pathology, Universidade Federal Fluminense (UFF). We also acknowledge the financial support of the Coordenação de Aperfeiçoamento de Pessoal de Nível Superior (CAPES) and Conselho Nacional de Desenvolvimento Científico e Tecnológico (CNPq).

\section{References}

1. AIRES DE SOUSA M.; CRISOSTOMO M.I.; SANCHES I.S.; WU J.S.;FUZHONG J.; TOMASZ A. ; DE LENCASTRE H. Frequent recovery of a single clonal type of multidrug-resistant Staphylococcus aureus from patients in two hospitals in Taiwan and China. J Clin Microbiol.v. 41, n. 1, p. 159-163, Jan. 2003.
2. AIRES DE SOUSA M.; DE LENCASTRE H.; SANTOS SANCHES I.; KIKUCHI K.; TOTSUKA K. ; TOMASZ A. Similarity of antibiotic resistance patterns and molecular typing properties of methicillin-resistant Staphylococcus aureus isolates widely spread in hospitals in New York City and in a hospital in Tokyo, Japan. Microb Drug Resist. v. 6, n. 3, p. 253-258, Fall. 2000.

3. AIRES DE SOUSA M.; MIRAGAIA M.; SANCHES I.S.; AVILA S.; ADAMSONI.; CASAGRANDE S.T.; BRANDILEONE M.C.; PALACIO R.; DELL'ACQUA L.; HORTAL M.; CAMOU T.; ROSSI A.; VELAZQUEZ-MEZA M.E.; ECHANIZAVILES G.; SOLORZANO-SANTOS F.; HEITMANN I. ; DE LENCASTRE H. Three-year assessment of methicillinresistant Staphylococcus aureus clones in Latin America from 1996 to 1998. J Clin Microbiol. Lisboa, v. 39, n. 6, p. $2197-$ 2205, Jun. 2001.

4. ALLEGRANZI B.; BAGHERI NEJAD S.; COMBESCURE C.; GRAAFMANS W.; ATTAR H.; DONALDSON L. ; PITTET D. Burden of endemic healthcare-associated infection in developing countries: systematic review and metaanalysis. Lancet. Geneva, v. 377, n. 9761, p. 228-241, Jan 15. 2011.

5. BERGLUNDC.; MOLLINGP.;SJOBERG L. ; SODERQUIST B. Predominance of staphylococcal cassette chromosome mec (SCCmec) type IV among methicillinresistant Staphylococcus aureus (MRSA) in a Swedish county and presence of unknown SCCmec types with Panton-Valentine leukocidin genes. Clin Microbiol Infect. Orebro, v. 11, n. 6, p. 447-456, Jun. 2005.

6. BRASIL Lei 9431 de 6 de março de 1997. Dispõem sobre a obrigatoriedade da manutenção de programa de controle de infecções hospitalares pelos hospitais do país. Diário Oficial da República Federativa do Brasil, Brasília, DF. [cited 2009, 03 set.]. Available from: http://www6.senado.gov.br/sicon/ ExecutaPesquisaLegislacao 
7. CECCARELli G.; D'ETtORRE G. ; VULlO V. Purulent Meningitis as an Unusual Presentation of Staphylococcus aureus Endocarditis: A Case Report and Literature Review. Case Report Med. v. 2011, n. p. 7352-7365, 2011.

8. CHAMBERS H.F. ; DELEO F.R. Waves of resistance: Staphylococcus aureus in the antibiotic era. Nat Rev Microbiol. San Francisco, v. 7, n. 9, p. 629-641, Sep. 2009.

9. CHARLEBOIS E.D.; BANGSBERG D.R.; MOSS N.J.; MOORE M.R.; MOSS A.R.; CHAMBERS H.F. ; PERDREAUREMINGTON F. Population-based community prevalence of methicillinresistant Staphylococcus aureus in the urban poor of San Francisco. Clin Infect Dis. San Francisco, v. 34, n. 4, p. 425433, Feb 15. 2002.

10. CONLY J.M.; JOHNSTON B.L. The emergence of methicillin-resistant Staphylococcus aureus as a communityacquired pathogen in Canada. Can J Infect Dis. v. 14, n. 5, p. 249-251, Sep. 2003.

11. COREY G.R. Staphylococcus aureus bloodstream infections: definitions and treatment. Clin Infect Dis. v. 48 Suppl 4, n. p. S254-259, May 15. 2009.

12. DAILEY L.; COOMBS G.W.; O'BRIEN F.G.;PEARMAN J.W.; CHRISTIANSEN K.; GRUBB W.B. ; RILEY T.V. Methicillin-resistant Staphylococcus aureus, Western Australia. Emerg Infect Dis. v. 11, n. 10, p. 1584-1590, Oct. 2005.

13. DANCER S.J. The effect of antibiotics on methicillin-resistant Staphylococcus aureus. J Antimicrob Chemother. v. 61, n. 2, p. 246-253, Feb. 2008.

14. DE MIRANDA O.P.; SILVACARVALHO M.C.; RIBEIRO A.; PORTELA F.; CORDEIRO R.P.; CAETANO N.; VIDAL C.F. ; FIGUEIREDO A.M. Emergence in Brazil of methicillin-resistant Staphylococcus aureus isolates carrying SCCmecIV that are related genetically to the USA800 clone. Clin Microbiol Infect. v. 13, n. 12, p. 1165-1172, Dec. 2007.

15. DEURENBERG R.H. ; STOBBERINGH E.E. The evolution of Staphylococcus aureus. Infect Genet Evol. Maastricht, v. 8, n. 6, p. 747-763, Dec. 2008.

16. The molecular evolution of hospitaland community-associated methicillinresistant Staphylococcus aureus. Curr Mol Med. v. 9, n. 2, p. 100-115, Mar. 2009.

17. DOS SANTOS SOARES M.J.; DA SILVA-CARVALHO M.C.; FERREIRACARVALHO B.T. ; FIGUEIREDO A.M. Spread of methicillin-resistant Staphylococcus aureus belonging to the Brazilian epidemic clone in a general hospital and emergence of heterogenous resistance to glycopeptide antibiotics among these isolates. J Hosp Infect. v. 44, n. 4, p. 301-308, Apr. 2000.

18. ERIKSEN K.R. [“Celbenin"-resistant staphylococci]. Ugeskr Laeger. v. 123, n. p. 384-386, Mar 17. 1961.

19. FORTES C.Q.; ESPANHA C.A.; BUSTORFF F.P.; ZAPPA B.C.; FERREIRA A.L.; MOREIRA R.B.; PEREIRA N.G.; FOWLER V.G., JR. ; DESHMUKH H. First reported case of infective endocarditis caused by community-acquired methicillin-resistant Staphylococcus aureus not associated with healthcare contact in Brazil. Braz J Infect Dis. v. 12, n. 6, p. 541-543, Dec. 2008.

20. FOWLER V.G., JR.; MIRO J.M.; HOEN B.; CABELL C.H.; ABRUTYN E.; RUBINSTEIN E.; COREY G.R.; SPELMAND.; BRADLEY S.F.;BARSIC B.; PAPPAS P.A.; ANSTROM K.J.; WRAY D.; FORTES C.Q.; ANGUERA I.; ATHAN E.; JONES P.; VAN DER MEER J.T.; ELLIOTT T.S.; LEVINE D.P. ; BAYER A.S. Staphylococcus aureus endocarditis: a consequence of medical progress. JAMA. v. 293, n. 24, p. 3012-3021, Jun 22. 2005. 
21. GENESTIER A.L.; MICHALLET M.C.; PREVOST G.; BELLOT G.; CHALABREYSSE L.; PEYROL S.; THIVOLET F.; ETIENNE J.; LINA G.; VALLETTE F.M.; VANDENESCH F. ; GENESTIER L. Staphylococcus aureus Panton-Valentine leukocidin directly targets mitochondria and induces Bax-independent apoptosis of human neutrophils. J Clin Invest. Lyon, v. 115, n. 11, p. 3117-3127, Nov. 2005.

22. GORWITZ R.J. Understanding the success of methicillin-resistant Staphylococcus aureus strains causing epidemic disease in the community. J Infect Dis. v. 197, n. 2, p 179-182, Jan 15. 2008.

23. HANSSEN A.M. ; ERICSON SOLLID J.U. SCCmec in staphylococci: genes on the move. FEMS Immunol Med Microbiol. v. 46, n. 1, p. 8-20, Feb. 2006.

24. ITOT.;MAX.X.;TAKEUCHIF.;OKUMA K.; YUZAWA H. ; HIRAMATSU K. Novel type V staphylococcal cassette chromosome mec driven by a novel cassette chromosome recombinase, ccrC. Antimicrob Agents Chemother. v. 48, n. 7, p. 2637-2651, Jul. 2004.

25. International Working Group on the Staphylococcal Cassette Chromosome elements. Currently identified SCCmec types in $S$. aureus strains. Japan: IWGSCC elements; 2009-2010 [cited 2011, 26 Dec]. Available from: http://www. sccmec.org/Pages/SCC TypesEN.html.

26. JEVONS M.P.; COE A.W. ; PARKER M.T. Methicillin resistance in staphylococci. Lancet. v. 1, n. 7287, p. 904-907, Apr 27. 1963.

27. KATAYAMA Y.; ITO T. ; HIRAMATSU K. A new class of genetic element, staphylococcus cassette chromosome mec, encodes methicillin resistance in Staphylococcus aureus. Antimicrob Agents Chemother. Tokyo, v. 44, n. 6, p. 1549-1555, Jun. 2000.
28. KENNEDY A.D.; OTTOM.;BRAUGHTON K.R.; WHITNEY A.R.; CHEN L.; MATHEMA B.; MEDIAVILLA J.R.; BYRNE K.A.; PARKINS L.D.; TENOVER F.C.; KREISWIRTH B.N.; MUSSER J.M. ; DELEOF.R. Epidemic community-associated methicillin-resistant Staphylococcus aureus: recent clonal expansion and diversification. Proc Natl Acad Sci US A. v. 105, n. 4, p. 1327-1332, Jan 29. 2008.

29. KLEVENS R.M.; MORRISON M.A.; NADLE J.; PETIT S.; GERSHMAN K.; RAY S.; HARRISON L.H.; LYNFIELD R.; DUMYATI G.; TOWNES J.M.; CRAIG A.S.; ZELL E.R.; FOSHEIM G.E.; MCDOUGAL L.K.; CAREY R.B. ; FRIDKIN S.K. Invasive methicillinresistant Staphylococcus aureus infections in the United States. JAMA. v. 298, n. 15, p. 1763-1771, Oct 17. 2007.

30. KONDO Y.; ITO T.; MA X.X.; WATANABE S.; KREISWIRTH B.N.; ETIENNE J. ; HIRAMATSU K. Combination of multiplex PCRs for staphylococcal cassette chromosome mec type assignment: rapid identification system for mec, ccr, and major differences in junkyard regions. Antimicrob Agents Chemother. v. 51, n. 1, p. 264-274, Jan. 2007.

31. LEE B.Y.; MCGLONE S.M.; WONG K.F.; YILMAZ S.L.; AVERY T.R.; SONG Y.; CHRISTIE R.; EUBANK S.; BROWN S.T.; EPSTEIN J.M.; PARKER J.I.; BURKE D.S.; PLATT R. ; HUANG S.S. Modeling the Spread of Methicillin-Resistant Staphylococcus aureus (MRSA) Outbreaks throughout the Hospitals in Orange County, California. Infect Control Hosp Epidemiol. v. 32, n. 6, p. 562-572, Jun. 2011.

32. LINDSAY J.A. ; HOLDEN M.T. Staphylococcus aureus: superbug, super genome? Trends Microbiol. London, v. 12, n. 8, p. 378-385, Aug. 2004.

33. LO W.T. ; WANG C.C. Panton-Valentine leukocidin in the pathogenesis of community-associated methicillin-resistant Staphylococcus aureus infection. Pediatr Neonatol. v. 52, n. 2, p. 59-65, Apr. 2011. 
34. MELO M.C.; SILVA-CARVALHO M.C.; FERREIRA R.L.; COELHO L.R.; SOUZA R.R.; GOBBI C.N.; ROZENBAUM R.; SOLARI C.A.; FERREIRACARVALHO B.T. ; FIGUEIREDO A.M. Detection and molecular characterization of a gentamicin-susceptible, methicillinresistant Staphylococcus aureus (MRSA) clone in Rio de Janeiro that resembles the New York/Japanese clone. J Hosp Infect. v. 58, n. 4, p. 276-285, Dec. 2004.

35. MELTER O.; SANTOS SANCHES I.; SCHINDLER J.; AIRES DE SOUSA M.; MATO R.; KOVAROVA V.; ZEMLICKOVA H. ; DE LENCASTRE H. Methicillin-resistant Staphylococcus aureus clonal types in the Czech Republic. J Clin Microbiol. v. 37, n. 9, p. 27982803, Sep. 1999.

36. NAIMI T.S.; LEDELL K.H.; COMOSABETTI K.; BORCHARDT S.M.; BOXRUD D.J.; ETIENNE J.; JOHNSON S.K.; VANDENESCH F.; FRIDKIN S.; O'BOYLE C.; DANILA R.N. ; LYNFIELD R. Comparison of community- and health care-associated methicillin-resistant Staphylococcus aureus infection. JAMA. v. 290, n. 22, p. 2976-2984, Dec 10. 2003.

37. OLIVEIRA G.A.; FARIA J.B.; LEVY C.E. ; MAMIZUKA E.M. Characterization of the Brazilian endemic clone of methicillin-resistant Staphylococcus aureus (MRSA) from hospitals throughout Brazil. Braz J Infect Dis. v. 5, n. 4, p. 163-170, Aug. 2001.

38. PEREZ L.R. ; D'AZEVEDO P.A. Clonal types and antimicrobial resistance profiles of methicillin-resistant Staphylococcus aureus isolates from hospitals in south Brazil. Rev Inst Med Trop Sao Paulo. v. 50, n. 3, p. 135-137, May-Jun. 2008.

39. RAMMELKAMP C.H. ; MAXON T. Resistance of Staphylococcus aureus to the Action of Penicillin. Proc Soc Exp Biol Med. v. 51, n. p. 386-389, December 1942.

40. RAMOS R.L.; TEIXEIRA L.A.; ORMONDE L.R.; SIQUEIRA P.L.;
SANTOS M.S.; MARANGONI D. ; FIGUEIREDO A.M. Emergence of mupirocin resistance in multiresistant Staphylococcus aureus clinical isolates belonging to Brazilian epidemic clone III::B:A. J Med Microbiol. v. 48, n. 3, p. 303-307, Mar. 1999.

41. REINERT C.; MCCULLOCH J.A.; WATANABE S.; ITO T.; HIRAMATSU K. ; MAMIZUKA E.M. Type IV SCCmec found in decade old Brazilian MRSA isolates. Braz J Infect Dis. v. 12, n. 3, p. 213-216, Jun. 2008.

42. RIBEIRO A.; CORONADO A.Z.; SILVA-CARVALHO M.C.; FERREIRACARVALHO B.T.; DIAS C; ROZENBAUM R.; DEL PELOSO P.F.; DA COSTA FERREIRA LEITE C.; TEIXEIRA L.A. ; FIGUEIREDO A.M. Detection and characterization of international communityacquired infections by methicillin-resistant Staphylococcus aureus clones in Rio de Janeiro and Porto Alegre cities causing both community- and hospital-associated diseases. Diagn Microbiol Infect Dis. v. 59, n. 3, p. 339-345, Nov. 2007.

43. RIBEIRO A.; DIAS C.; SILVACARVALHO M.C.; BERQUO L.; FERREIRA F.A.; SANTOS R.N.; FERREIRA-CARVALHO B.T. ; FIGUEIREDO A.M. First report of infection with community-acquired methicillinresistant Staphylococcus aureus in South America. J Clin Microbiol. v. 43, n. 4, p. 1985-1988, Apr. 2005.

44. RIZEK C.F.; MATTE M.H.; DROPA M.; MAMIZUKA E.M.; DE ALMEIDA L.M.; LINCOPAN N.; MATTE G.R. ; GERMANO P.M. Identification of Staphylococcus aureus carrying the mecA gene in ready-to-eat food products sold in Brazil. Foodborne Pathog Dis. v. 8, n. 4, p. 561-563, Apr. 2011.

45. ROBINSON D.A. ; ENRIGHT M.C. Multilocus sequence typing and the evolution of methicillin-resistant Staphylococcus aureus. Clin Microbiol Infect. Bath, v. 10, n. 2, p. 92-97, Feb. 2004. 
46. RODRIGUEZ-NORIEGA E. ; SEAS C. The changing pattern of methicillinresistant staphylococcus aureus clones in Latin America: implications for clinical practice in the region. Braz J Infect Dis. v. 14 Suppl 2, n. p. S87-96, Dec. 2010.

47. RODRIGUEZ-NORIEGA E.; SEAS C.; GUZMAN-BLANCO M.; MEJIA C.; ALVAREZ C.; BAVESTRELLO L.; ZURITA J.; LABARCA J.; LUNA C.M.; SALLES M.J. ; GOTUZZO E. Evolution of methicillin-resistant Staphylococcus aureus clones in Latin America. Int J Infect Dis. v. 14, n. 7, p. e560-566, Jul. 2010.

48. ROSSI F. The challenges of antimicrobial resistance in Brazil. Clin Infect Dis. v. 52, n. 9, p. 1138-1143, May. 2011.

49. ROZENBAUM R.; SAMPAIO M.G.; BATISTA G.S.; GARIBALDI A.M.; TERRA G.M.; SOUZA M.J.; VIEIRA E.N.; SILVA-CARVALHO M.C.; TEIXEIRA L.A. ; FIGUEIREDO A.M. The first report in Brazil of severe infection caused by community-acquired methicillin-resistant Staphylococcus aureus (CA-MRSA). Braz J Med Biol Res. v. 42, n. 8, p. 756-760, Aug. 2009.

50. ROZENBAUM R.; SILVA-CARVALHO M.C.; SOUZA R.R.; MELO M.C.; GOBBI C.N.; COELHO L.R.; FERREIRA R.L.; FERREIRA-CARVALHO B.T.; SCHUENCK A.L.; NEVES F.M.; SILVA L.R. ; FIGUEIREDO A.M. Molecular characterization of methicillin-resistant Staphylococcus aureus disseminated in a home care system. Infect Control Hosp Epidemiol. v. 27, n. 10, p. 1041-1050, Oct. 2006.

51. SA-LEAO R.; SANTOS SANCHES I.; DIAS D.; PERES I.; BARROS R.M. ; DE LENCASTRE H. Detection of an archaic clone of Staphylococcus aureus with lowlevel resistance to methicillin in a pediatric hospital in Portugal and in international samples: relics of a formerly widely disseminated strain? J Clin Microbiol. v. 37, n. 6, p. 1913-1920, Jun. 1999.
52. SADER H.S.; PIGNATARI A.C.; HOLLIS R.J. ; JONES R.N. Evaluation of interhospital spread of methicillinresistant Staphylococcus aureus in Sao Paulo, Brazil, using pulsed-field gel electrophoresis of chromosomal DNA. Infect Control Hosp Epidemiol. v. 15, n. 5, p. 320-323, May. 1994.

53. SAID-SALIM B.; MATHEMA B.; BRAUGHTON K.; DAVIS S.; SINSIMER D.;EISNERW.;LIKHOSHVAYY.;DELEO F.R. ; KREISWIRTH B.N. Differential distribution and expression of PantonValentine leucocidin among communityacquired methicillin-resistant Staphylococcus aureus strains. J Clin Microbiol. Newark, v. 43, n. 7, p. 3373-3379, Jul. 2005.

54. SCHUENCK R.P.; NOUER S.A.; WINTER CDE O.; CAVALCANTE F.S.; SCOTTI T.D.; FERREIRA A.L.; GIAMBIAGI-DE MARVAL M. ; DOS SANTOS K.R. Polyclonal presence of non-multiresistant methicillin-resistant Staphylococcus aureus isolates carrying SCCmec IV in health care-associated infections in a hospital in Rio de Janeiro, Brazil. Diagn Microbiol Infect Dis. v. 64, n. 4, p. 434-441, Aug. 2009.

55. SCRIBEL L.V.; SILVA-CARVALHO M.C.; SOUZA R.R.; SUPERTI S.V.; KVITKO C.H.; FIGUEIREDO A.M. ; ZAVASCKI A.P. Clinical and molecular epidemiology of methicillin-resistant Staphylococcus aureus carrying SCCmecIV in a university hospital in Porto Alegre, Brazil. Diagn Microbiol Infect Dis. v. 65, n. 4, p. 457-461, Dec. 2009

56. SHORE A.C.; DEASY E.C.; SLICKERS P.; BRENNAN G.; O'CONNELL B.; MONECKES.;EHRICHTR.; COLEMAN D.C. Detection of Staphylococcal Cassette Chromosome mec Type XI Carrying Highly Divergent mecA, mecI, mecR1, blaZ, and ccr Genes in Human Clinical Isolates of Clonal Complex 130 Methicillin-Resistant Staphylococcus aureus. Antimicrob Agents Chemother. v. 55, n. 8, p. 3765-3773, Aug. 2011. 
57. SILVA-CARVALHO M.C.; BONELLI R.R.; SOUZA R.R.; MOREIRA S.; DOS SANTOS L.C.; DE SOUZA CONCEICAO M.; DE MELLO JUNIOR S.J.; CARBALLIDO J.M.; RITO P.N.; VIEIRA V.V.; TEIXEIRA L.A. ; SA FIGUEIREDO A.M. Emergence of multiresistant variants of the community-acquired methicillinresistant Staphylococcus aureus lineage ST1-SCCmecIV in 2 hospitals in Rio de Janeiro, Brazil. Diagn Microbiol Infect Dis. v. 65, n. 3, p. 300-305, Nov. 2009.

58. SOUSA-JUNIOR F.C.; SILVACARVALHO M.C.; FERNANDES M.J.; VIEIRA M.F.; PELLEGRINO F.L.; FIGUEIREDO A.M.; DE MELO M.C. ; MILAN E.P. Genotyping of methicillinresistant Staphylococcus aureus isolates obtained in the Northeast region of Brazil. Braz J Med Biol Res. v. 42, n. 10, p. 877881, Oct. 2009.

59. STEVENS M.P.; BEARMAN G.; ROSATO A. ; EDMOND M. Community-acquired methicillin resistant Staphylococcus aureus in a women's collegiate basketball team. South Med J. v. 101, n. 10, p. 1067-1068, Oct. 2008.

60. TEIXEIRA L.A.; RESENDE C.A.; ORMONDE L.R.; ROSENBAUM R.; FIGUEIREDO A.M.; DE LENCASTRE H. ; TOMASZ A. Geographic spread of epidemic multiresistant Staphylococcus aureus clone in Brazil. J Clin Microbiol. v. 33, n. 9, p. 2400-2404, Sep. 1995.

61. UDO E.E.; PEARMAN J.W. ; GRUBB W.B. Genetic analysis of community isolates of methicillin-resistant Staphylococcus aureus in Western Australia. J Hosp Infect. v. 25, n. 2, p. 97108, Oct. 1993.
62. VANDENESCH F.; NAIMI T.; ENRIGHT M.C.; LINA G.; NIMMO G.R.; HEFFERNAN H.; LIASSINE N.; BES M.; GREENLAND T.; REVERDY M.E. ; ETIENNE J. Community-acquired methicillin-resistant Staphylococcus aureus carrying Panton-Valentine leukocidin genes: worldwide emergence. Emerg Infect Dis. v. 9, n. 8, p. 978-984, Aug. 2003.

63. VIVONI A.M.; DIEP B.A.; DE GOUVEIA MAGALHAES A.C.; SANTOS K.R.; RILEY L.W.; SENSABAUGH G.F. ; MOREIRA B.M. Clonal composition of Staphylococcus aureus isolates at a Brazilian university hospital: identification of international circulating lineages. J Clin Microbiol. v. 44, n. 5, p. 1686-1691, May. 2006.

64. WALRAVEN C.J.; LINGENFELTER E.; ROLLO J.; MADSEN T. ; ALEXANDER D.P. Diagnostic and Therapeutic Evaluation of Community-acquired Methicillin-resistant Staphylococcus Aureus (MRSA) Skin and Soft Tissue Infections in the Emergency Department. J Emerg Med. n. p., Apr 25. 2011.

65. ZHANG K.; MCCLURE J.A.; ELSAYED S. ; CONLY J.M. Novel staphylococcal cassette chromosome mec type, tentatively designated type VIII, harboring class A mec and type 4 ccr gene complexes in a Canadian epidemic strain of methicillin-resistant Staphylococcus aureus. Antimicrob Agents Chemother. v. 53, n. 2, p. 531-540, Feb. 2009. 
Anexos

Table 1. Main types of Staphylococcal Cassette Chromosome mec found in Brazil

(HANSSEN \& ERICSON SOLLID, 2006; DEURENBERG \& STOBBERINGH, 2008; CHAMBERS \& DELEO, 2009; IWG-SCC, 2011).

\begin{tabular}{|c|c|c|}
\hline \multirow{2}{*}{ Characteristics } & \multicolumn{2}{|c|}{ SCCmec type } \\
\cline { 2 - 3 } & III & IV \\
\hline length $(\mathrm{Kb})$ & $60-67$ & $21-24$ \\
\hline mec gene complex & A & B \\
\hline ccr gene complex & A3B3 & A2B2 \\
\hline Numbers of IS431 & 4 & 0 \\
\hline Numbers of Tn554 & 2 & $(-)$ \\
\hline pUB110 & $(-)$ & $(-)$ \\
\hline pT181 & $(+)$ & $(-)$ \\
\hline pI158 & $(+)$ & $(-)$ \\
\hline
\end{tabular}

IS: Insertion Sequence; Tn: Transposon; p: plasmid; Erm: erythromycin resistance gene; tc: tetracycline resistance gene; Hg: mercury resistance gene; $(+)$ : presence; $(-)$ : ausence.

Table 2. Comparison of infections associated with community setting (CA-MRSA) and hospitalacquired infections (HA-MRSA).

\begin{tabular}{|c|c|c|c|}
\hline \multirow{2}{*}{ Characteristics } & \multicolumn{2}{|c|}{ Type of MRSA } & \multirow[t]{2}{*}{ References } \\
\hline & HA & CA & \\
\hline Year of discovery & 1961 & 1993 & $\begin{array}{c}\text { (DEURENBERG \& } \\
\text { STOBBERINGH, 2008) }\end{array}$ \\
\hline $\begin{array}{l}\text { Risk factor for } \\
\text { infection }\end{array}$ & $\begin{array}{c}\text { Inpatients, users } \\
\text { of intravenous } \\
\text { catheter,patients on } \\
\text { dialysis, burned.of } \\
\text { intravenous catheter, } \\
\text { patients on dialysis, } \\
\text { burned. }\end{array}$ & $\begin{array}{l}\text { Children, athletes, } \\
\text { prisoners, miitary, } \\
\text { injecting drug users, } \\
\text { men who have sex } \\
\text { with men, HIV- } \\
\text { positive }\end{array}$ & $\begin{array}{l}\text { (CHARLEBOIS, 2002; } \\
\text { STEVENS, 2008) }\end{array}$ \\
\hline $\begin{array}{l}\text { Main clinical } \\
\text { manifestations }\end{array}$ & $\begin{array}{l}\text { Bacteremia, hospital- } \\
\text { acquired pneumonia, } \\
\text { ventilator-associated } \\
\text { pneumonia. }\end{array}$ & $\begin{array}{l}\text { Skin and subcutaneous } \\
\text { tissue infections, } \\
\text { community acquired } \\
\text { pneumonia, } \\
\text { bacteremia, } \\
\text { osteomyelitis. }\end{array}$ & $\begin{array}{l}\text { (NAIMI, 2003; LO \& } \\
\text { WANG, 2011) }\end{array}$ \\
\hline Type of SCCmec & I, II, III & IV, V, VII & $\begin{array}{c}\text { (CHAMBERS \& DELEO, } \\
\text { 2009) }\end{array}$ \\
\hline $\begin{array}{l}\text { antimicrobial } \\
\text { resistance }\end{array}$ & $\begin{array}{l}\text { Multiresistant. Including } \\
\beta \text {-lactams, macrolides, } \\
\text { TMP-SMX, lincosamides, } \\
\text { tetracyclines, rifampin, } \\
\text { quinolones and } \\
\text { glicopepitide resistance } \\
\text { cases. }\end{array}$ & $\begin{array}{l}\beta \text {-lactams. Variable } \\
\text { susceptibility to } \\
\text { macrolides, TMP- } \\
\text { SMX, tetracyclines } \\
\text { and lincosamides. }\end{array}$ & (WALRAVEN, 2011) \\
\hline PVL Production & Rare & Frequent & (VANDENESCH, 2003) \\
\hline
\end{tabular}

TMP-SMX: Trimethoprim-sulfamethoxazole 


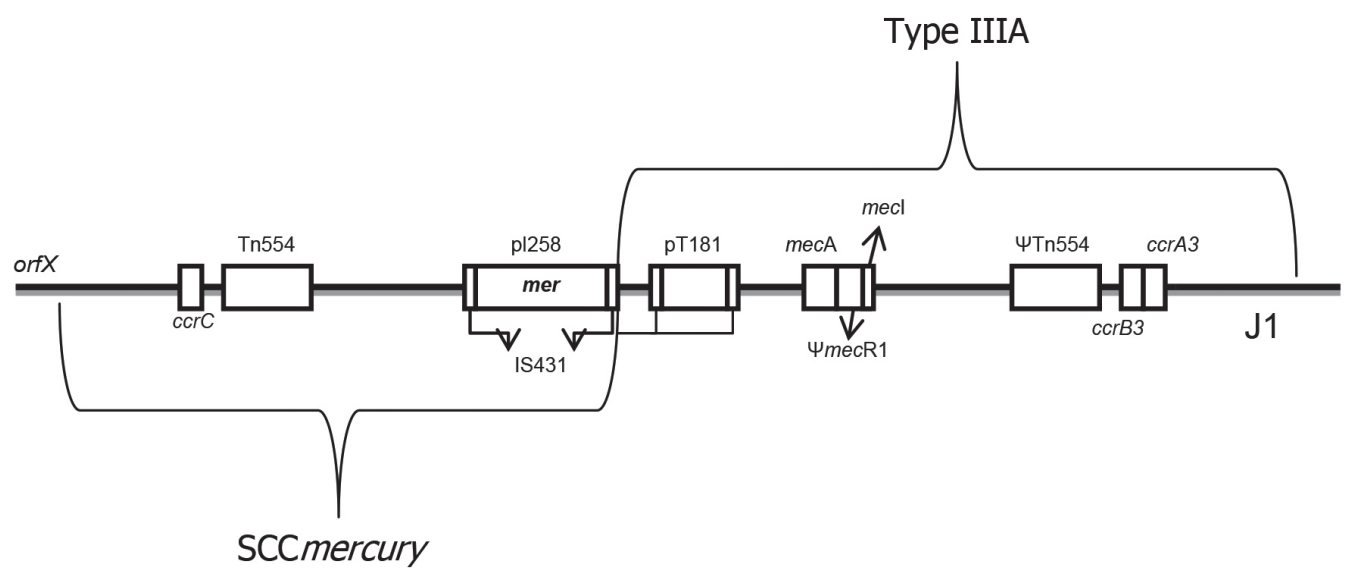

IS: Insertion Sequence; Tn: Transposon; p: plasmid; orf: open reading frame; $\boldsymbol{m e c} \boldsymbol{A}$ : gene that encodes PBP2; $\boldsymbol{m e c R} \mathbf{1}$ and $\boldsymbol{m e c I}$ : genes that control mecA expression, encoding the signal transducer protein ecR1 or encoding the repressor protein MecI, respectively; ccr: cassette chromosome recombinases; mer: mercury resistance operon; $\mathbf{J}$ : J regions, which constitute nonessential components of the cassette.

Figure 2 - MRSA clones circulating in Brazil.

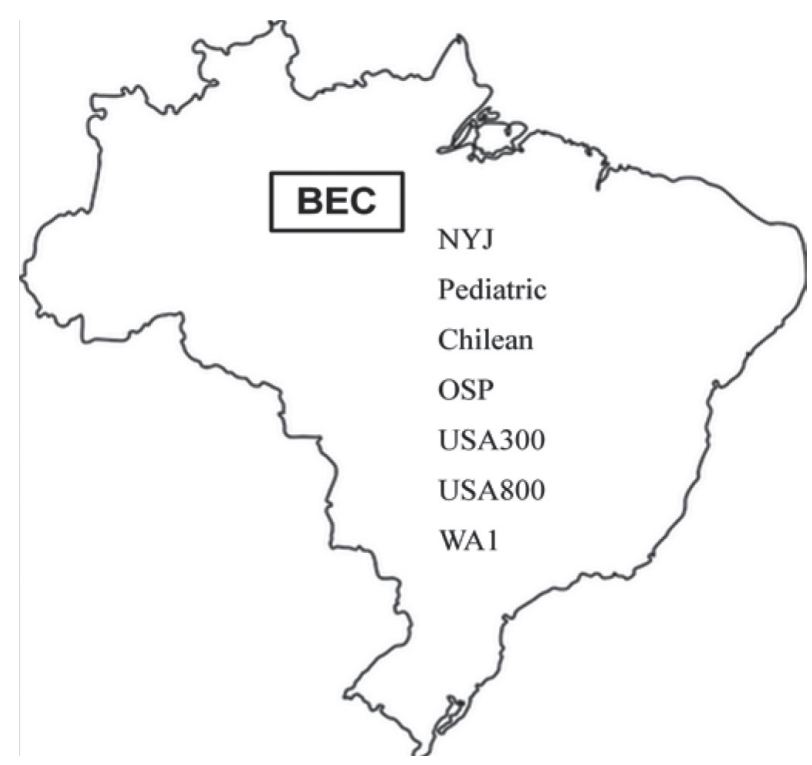

BEC: Brazilian Epidemic Clone; OSP: Oceania Southwest Pacific clone; NYJ: New York/Japan clone; WA1: Western Australia 1 clone 